\title{
Acute inhalation toxicity of cotton plant dusts
}

\author{
RAGNAR RYLANDER and MARIE-CLAIRE SNELLA \\ Department of Environmental Hygiene, University of Gothenburg, Sweden and Division of \\ Environmental Medicine, Institute of Social and Preventive Medicine, University of Geneva, \\ Switzerland
}

\begin{abstract}
Rylander, R. and Snella, M.-C. (1976). British Journal of Industrial Medicine, 33, 175-180. Acute inhalation toxicity of cotton plant dusts. The number of free lung-cells was studied in guinea-pigs after acute exposure to extracts of various cotton dusts. A good correlation was found between the increase in number of leucocytes in the airways and the number of Gram-negative bacteria in the different dusts. Experiments using the Shwartzmann reaction and the Limulus titration test demonstrated a relationship between the content of different endotoxins in the dusts and the pulmonary reaction. A model for the acute exposure effects after exposure to cotton dust is proposed.
\end{abstract}

The relationship between exposure to cotton dust and the prevalence of byssinosis has been known for several years. As it at present does not seem to be feasible technically to eliminate the dust exposure in cotton plants completely, further knowledge about the causative agent in the dust is not only of scientific but of practical value.

It has previously been shown (Rylander and Nordstrand, 1974) that exposure to a water extract of cotton dust trash will increase the number of polymorphonuclear leucocytes in the airways of guinea-pigs. The maximum is reached after about 24 hours' exposure and the extent of the reaction is dependent on the dose.

It has also been demonstrated that the leucocyte reaction is related to the amount of bacteria in several organic dusts (Rylander, Nordstrand, and Snella, 1975a). When cotton, hay, or jute were stored under humid conditions, an increase in the toxicity was found in cases where the amount of bacteria increased. In certain preparations, the presence of moulds prevented the increase of bacteria. After exposure to extracts of such preparations, no increase was found in the number of leucocytes in the airways. When different strains of bacteria found in the cotton dusts were tested in acute inhalation experiments it was found that certain Gram-negatives produced the largest reactions
(Rylander, Snella, and Garcia, 1975b), but other bacteria such as Bacillus subtilis and moulds did not influence the number of leucocytes in the airways. Gram-negative bacteria were later cultivated from all cotton plants and cotton dusts so far tested.

The present experiments were undertaken to study the relationship between the leucocyte reaction and the contamination with Gram-negatives in different types of cotton dusts. Animals were exposed to a water extract of the different dusts tested and the number of macrophages and leucocytes in the airways was determined 24 hours later. The total number of bacteria and the number of Gram-negatives was determined in the extracts. Additional experiments using the Shwartzmann reaction and the Limulus titration test were undertaken on certain samples selected during the first part of the study. The effects of alkaline and acid treatment of the extract were studied on one dust sample and a suspension of Gram-negative bacteria.

\section{Materials and methods}

Cotton plant material

Samples of bract from different geographical locations were used in the experiments. The bract was hand-picked before harvesting the cotton and micronized samples of different commercial bale cottons were obtained from 
various places. Cotton was also picked directly from cotton plants without contamination of bract.

Gin mill trash was taken from a cotton gin. Other dusts were obtained from various locations in cotton processing plants.

All samples were stored in the laboratory before use $\left(20^{\circ}, 15-30 \%\right.$ relative humidity). One sample of bale cotton was stored in $37^{\circ} \mathrm{C}$ under $100 \%$ relative humidity for three months, after which it was left to dry in room air.

\section{Preparation of extracts}

Water extracts were prepared from the different bracts and dusts by suspending $5 \mathrm{~g}$ in $60 \mathrm{ml}$ sterile distilled water and shaking vigorously for 15 minutes. To prepare extracts from the cotton, $5 \mathrm{~g}$ was suspended in $60 \mathrm{ml}$ water; it was then shaken and the liquid squeezed out. This liquid was again added to the cotton and the process was repeated five times. Control experiments demonstrated that no further increase in the number of bacteria in the liquid was obtained with additional washings.

The number of bacteria in the different extracts was determined by inoculating $0.5 \mathrm{ml}$ of serial dilutions in ordinary agar and endoagar pour plates. The number of colonies was counted 24 hours after incubation at $37^{\circ} \mathrm{C}$.

\section{Treatment with acid and alkali}

The extract of one bract sample and a suspension of Enterobacter aerogenes were subjected to treatment with acid or alkali. $\mathrm{HCl}$ was added until $\mathrm{pH} 3$ was reached. The preparation was then boiled for 30 minutes. For the alkali treatment the bract extract was diluted $1: 10$ in $1 \mathrm{M} \mathrm{NaOH}$ (pH 11.4). After boiling for 20 minutes and agitating for 24 hours, the extract was dialyzed against $0.9 \% \mathrm{NaCL}$ with frequent changes of this fluid for 48 hours. Control preparations were similarly treated without addition of $\mathrm{NaOH}$.

\section{Animals and exposures}

Guinea-pigs weighing $250-400 \mathrm{~g}$ were used. They were of a breeding nucleus raised under infection-controlled conditions at the Institute for Tiersucht, Canton Hospital in Zürich. They were kept under normal conditions before being used one to two weeks after delivery.

The exposures were performed according to a method previously used (Rylander and Nordstrand, 1974). The extracts were placed in a Collison spray for aerolization and the aerosol was fed into an exposure chamber. The exposure lasted 40 minutes.

\section{Determination of the exposure effect}

The number of free lung cells was determined 24 hours after exposure using the technique earlier described (Rylander, 1971). The animals were killed intraperitoneally with an injection of sodium pentothal. After death a syringe was connected to the trachea and $10 \mathrm{ml}$ of $0.9 \%$ saline was gently flushed into the lungs and withdrawn. The same fluid was then flushed in again and withdrawn - the process was repeated 10 times altogether. Thereafter a sample of the fluid was transferred into a test-tube and stained. The preparation was studied under the microscope and the number of macrophages and polymorphonuclear leucocytes was determined. Differ- ences between the average values from control and treated animals were evaluated using the Student's $t$ test. Significant differences were given as $P \leqslant 0.01$ and $P \leqslant 0.001$.

\section{Shwartzmann reaction}

The presence of endotoxins in certain of the extracts studied was determined using the Shwartzmann reaction.

$0.1 \mathrm{ml}$ of the cotton extract was injected intradermally on the back of a rabbit. 24 hours later, $20 \mu \mathrm{g}$ of LPS 026:B6 were injected intravenously together with $1 \mathrm{ml}$ of a $2 \%$ solution of Evan's blue. The animals were killed 24 hours afterwards, the skin was removed, and the surface of the blue necrotizing zone at the intradermal injection site was measured from the inside.

\section{Limulus titration}

Serial dilutions were prepared from the different bract extracts and $0.1 \mathrm{ml}$ of Limulus lysate was added to $0.1 \mathrm{ml}$ of dilution. The results were read after 1 hour of incubation at $37^{\circ} \mathrm{C}$ and reported as the last dilution giving a stable cloth formation before two successive dilutions giving a negative result.

\section{Results}

Altogether 138 animals were used in the study and 16 cotton dust samples were examined. An additional 50 animals taken from different batches of animals delivered served as controls.

Table 1 shows the number of macrophages and leucocytes found in the pulmonary lavage fluid 24 hours after exposure to water extracts of the different cotton dust preparations. The table also shows the log number of total bacteria and Gramnegatives per $\mathrm{ml}$ extract, and demonstrates that most of the bacteria found on the dust samples were Gram-negatives. The correlation between the total number of bacteria and the number of Gramnegatives was 0.98. The correlation between the individual number of macrophages and the Gramnegatives was $0.40 \pm 0.08$ which was statistically significant. The correlation between the individual number of leucocytes and Gram-negatives was $0.52 \pm 0.07$ which was also significant.

Table 1 and Fig. 1 show that exposure to extracts containing a low number of Gram-negative bacteria did not affect the number of leucocytes in the airways. At about 3.5 log number of bacteria per $\mathrm{ml}$ extract an increase was found. This became higher, the higher the number of bacteria in the extract.

Fig. 1 also shows that certain preparations with about the same number of Gram-negatives caused a different leucocyte reaction in the airways. The Shwartzmann test was performed on certain such samples in cases in which the leucocyte response differed, but the bacteria content was about the same (bract 73-9 and 73-10, trash 1, and picker dust 1).

The results from the exposures to extracts from 
TABLE 1

Number of Macrophages and Leucocytes $\left(\times 10^{5}\right)$ in Airways of Guinea-Pigs Exposed to Extracts: FROM DIFFERENT COTTON DUSTS

\begin{tabular}{|c|c|c|c|c|c|c|c|c|}
\hline \multicolumn{4}{|c|}{ Sample } & $\begin{array}{c}\begin{array}{c}\text { No. of } \\
\text { animals }\end{array} \\
50\end{array}$ & $\begin{array}{c}\text { Macrophages } \\
104(50 \cdot 3)\end{array}$ & $\begin{array}{c}\text { Leucocytes } \\
59(37 \cdot 8)\end{array}$ & $\begin{array}{c}\begin{array}{c}\text { Bacteria } \\
\text { total }\end{array} \\
-\end{array}$ & $\begin{array}{c}\begin{array}{c}\text { Gram- } \\
\text { negatives }\end{array} \\
-\end{array}$ \\
\hline $\begin{array}{l}\text { Control } \\
\text { Bract 73-4 } \\
\text { Bract 73-6 } \\
\text { Bract 73-9 } \\
\text { Bract 73-10 } \\
\text { Bract 73-11 } \\
\text { Bract 73-121 } \\
\text { Bract 73-13 } \\
\text { Trash I } \\
\text { Picker dust I } \\
\text { Picker dust II } \\
\text { Card dust } \\
\text { Trash II } \\
\text { Gin trash } \\
\text { Gin mill dust } \\
\text { Bale cotton } \\
\text { Plant cotton }\end{array}$ & 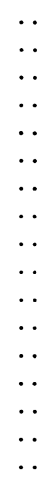 & $\begin{array}{l}\ldots \\
\ldots \\
\ldots \\
\cdots \\
\cdots \\
\ldots \\
\ldots \\
\ldots \\
\cdots \\
\ldots \\
\ldots \\
\cdots \\
\cdots \\
\cdots \\
\cdots \\
\ldots\end{array}$ & $\begin{array}{l}\ldots \\
\ldots \\
\ldots \\
\ldots \\
\ldots \\
\ldots \\
\ldots \\
\ldots \\
\cdots \\
\ldots \\
\ldots \\
\ldots \\
\cdots \\
\cdots \\
\cdots \\
\cdots \\
\ldots\end{array}$ & $\begin{array}{r}50 \\
10 \\
10 \\
10 \\
10 \\
10 \\
10 \\
10 \\
9 \\
10 \\
10 \\
10 \\
10 \\
5 \\
5 \\
5 \\
5\end{array}$ & $\begin{array}{c}104(50 \cdot 3) \\
115(37 \cdot 9) \\
210(99 \cdot 8) \\
163(55 \cdot 7) \\
147(61 \cdot 0) \\
140(73 \cdot 4) \\
218(85 \cdot 0) \\
94(42 \cdot 0) \\
228(130 \cdot 8) \\
184(51 \cdot 2) \\
174(92 \cdot 1) \\
160(57 \cdot 4) \\
250(104 \cdot 2) \\
102(59 \cdot 0) \\
125(78 \cdot 1) \\
179(61 \cdot 1) \\
204(45 \cdot 3)\end{array}$ & $\begin{array}{c}59(37 \cdot 8) \\
54(19 \cdot 9) \\
190(107 \cdot 4) \\
344(180 \cdot 9) \\
141(64 \cdot 2) \\
135(67 \cdot 9) \\
388(166 \cdot 5) \\
83(42 \cdot 4) \\
909(434 \cdot 5) \\
251(88 \cdot 7) \\
329(248 \cdot 1) \\
130(57 \cdot 0) \\
418(171 \cdot 5) \\
42(35 \cdot 8) \\
95(60 \cdot 8) \\
89(31 \cdot 1) \\
215(76 \cdot 5)\end{array}$ & $\begin{array}{l}3 \cdot 4 \\
3 \cdot 8 \\
4 \cdot 0 \\
4 \cdot 6 \\
3 \cdot 3 \\
6 \cdot 7 \\
3 \cdot 9 \\
6 \cdot 1 \\
6 \cdot 2 \\
5 \cdot 6 \\
4 \cdot 9 \\
6 \cdot 2 \\
2 \cdot 1 \\
4 \cdot 6 \\
4 \cdot 6 \\
5 \cdot 4\end{array}$ & $\begin{array}{l}-7 \cdot 4 \\
3 \cdot 7 \\
4 \cdot 1 \\
4 \cdot 6 \\
3 \cdot 0 \\
6 \cdot 7 \\
3 \cdot 1 \\
6 \cdot 1 \\
6 \cdot 2 \\
5 \cdot 6 \\
4 \cdot 6 \\
6 \cdot 2 \\
1 \cdot 3 \\
4 \cdot 5 \\
4 \cdot 4 \\
5 \cdot 3\end{array}$ \\
\hline
\end{tabular}

Log numbers of total and Gram-negative bacteria per $1 \mathrm{ml}$ of extract

Figures in parentheses represent standard deviation

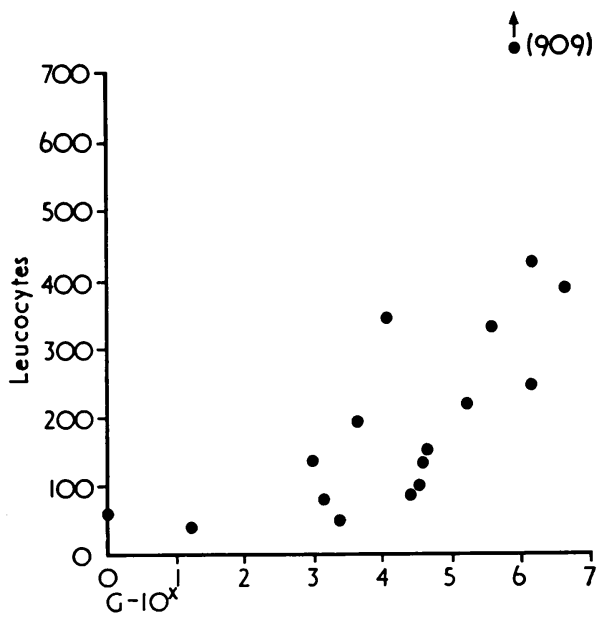

FIG. 1. Relationship between leucocyte response and amount of Gram-negative bacteria in different dusts. the bale cotton which had been stored under humid conditions are shown in Table 2.

Exposure to extract from dry cotton caused a small increase in the average number of macrophages and leucocytes which was not statistically significant. In extracts from cotton which had been stored for three months a marked increase in the number of bacteria was found. This extract also caused a large increase in the average number of macrophages and leucocytes in the airways $(P \leqslant 0.001)$.

The results of the Shwartzmann reaction from the different selected cotton samples are shown in Table 3.

For the two pairs of samples in which the bacterial count was about the same, the rank order of the size of the Shwartzmann reaction corresponded to the one for the leucocyte counts, except for samples 73-9 and 73-10 in the second test in which no difference was found.

The results from the tests of the selected cotton

TABLE 2

Number of Macrophages and Leucocytes $\left(\times 10^{5}\right)$ in Airways of Guinea-Pigs Exposed to Extracts from Bale Cotton Stored Under Humid Conditions

\begin{tabular}{|c|c|c|c|c|c|c|}
\hline Cotton & & $\begin{array}{c}\text { Bacteria } \\
\text { total }\end{array}$ & $\begin{array}{c}\text { Gram- } \\
\text { negative }\end{array}$ & Animals & Macrophages & Leucocytes \\
\hline $\begin{array}{lcc}\text { Control } & \ldots & \ldots \\
\text { Cotton dry } & \ldots & . \\
\text { Cotton humid three } & \text { months }\end{array}$ & $\begin{array}{l}\ldots \\
\cdots \\
\ldots\end{array}$ & $\begin{array}{l}\overline{4 \cdot 6} \\
7 \cdot 2\end{array}$ & $\begin{array}{l}\overline{4 \cdot 4} \\
7 \cdot 0\end{array}$ & $\begin{array}{r}10 \\
5 \\
5\end{array}$ & $\begin{array}{l}106(72 \cdot 5) \\
179(61 \cdot 1) \\
254(43 \cdot 8)\end{array}$ & $\begin{array}{r}65(39 \cdot 3) \\
89(31 \cdot 1) \\
235(59 \cdot 2)\end{array}$ \\
\hline
\end{tabular}

Log numbers of total and Gram-negative bacteria per $1 \mathrm{ml}$ of extract

Figures in parentheses represent standard deviation 
TABLE 3

Surface of Reaction (mm²) in Shwartzmann Test on Selected Cotton Dust Samples

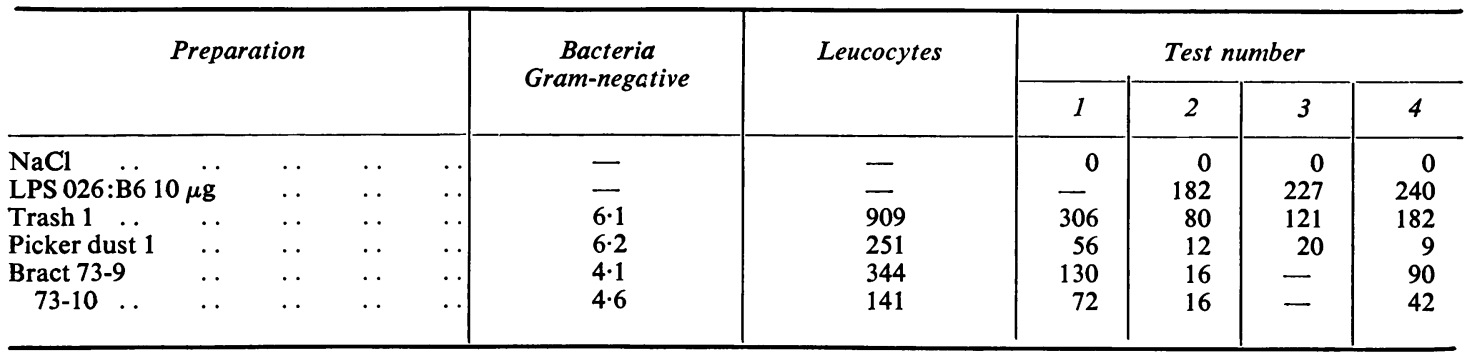

Data on bacteria and leucocytes from Table 1

TABLE 4

Lowest Concentration in Dry Weight of Dust Giving a Positive Limulus Reaction

\begin{tabular}{|c|c|c|c|c|}
\hline \multicolumn{3}{|c|}{ Preparation } & $\mu g / m l$ & Leucoctyes \\
\hline $\begin{array}{c}\text { Bract } \\
73-4 \\
73-6 \\
73-9 \\
73-10 \\
73-11 \\
73-121 \\
73-13\end{array}$ & $\begin{array}{l}\cdots \\
\ldots \\
\ldots \\
\ldots \\
\ldots \\
\ldots\end{array}$ & $\begin{array}{l}\ldots \\
\ldots \\
\ldots \\
\ldots \\
\ldots \\
\ldots\end{array}$ & $\begin{array}{r}41 \cdot 7 \\
5 \cdot 2 \\
5 \cdot 2 \\
5 \cdot 2 \\
10 \cdot 4 \\
2 \cdot 1 \\
10 \cdot 4\end{array}$ & $\begin{array}{r}54 \\
190 \\
344 \\
141 \\
135 \\
388 \\
83\end{array}$ \\
\hline
\end{tabular}

Data on leucocytes from Table 1

dusts using the Limulus titration are found in Table 4.

The correlation between the titration values and the individual number of leucocytes was $r_{\mathbf{x y}}=$ $-0.46 \pm 0.10$ which is statistically significant.

The results from the treatment with acid or alkali are illustrated in Table 5.
As can be seen exposure to an extract of bract 73-122 resulted in an increase in the average number of leucocytes $(P \leqslant 0.001)$. When the extract was boiled for 20 minutes a significantly larger amount of leucocytes appeared in the airways after exposure. After boiling at $\mathrm{pH} 3$ or $\mathrm{pH} 11.7$ the leucotactic effect disappeared. The same finding was present after exposure to Enterobacter before and after boiling for 30 minutes at $\mathrm{pH} 3$.

\section{Discussion}

The experiments were performed using a water extract of the different dust samples. Results earlier published from our laboratories demonstrated that exposure to an aerosol of dry bract dust will cause similar reactions concerning the quantity of macrophages and leucocytes in the airways (Rylander and Snella, 1974).

The effect criterion used in the present experiments was the increase in the number of leucocytes in the airways after an acute exposure. A similar response is found also in guinea-pigs kept in card-rooms (Hersh, 1973). The leucocyte reaction has been

TABLE 5

Number of Macrophages and Leucocytes $\left(\times 10^{5}\right)$ in Airways of Guinea-Pigs Exposed to Extracts of Bract or a Suspension of Enterobacter aerogenes Treated with ACID or AlKali

\begin{tabular}{|c|c|c|c|c|c|c|c|c|}
\hline \multicolumn{5}{|c|}{ Sample } & Treatment & No. of & Macrophages & Leucocytes \\
\hline $\begin{array}{l}\text { Control } \\
\text { Water pH } 3 \\
\text { Bract 73-122 } \\
73-122 \\
73-122 \\
73-122 \\
\text { Enterobacter } \\
\text { Enterobacter }\end{array}$ & $\begin{array}{l}\cdots \\
\cdots \\
\cdots \\
\cdots \\
\cdots \\
\cdots\end{array}$ & $\begin{array}{l}\ldots \\
\cdots \\
\ldots \\
\ldots \\
\cdots \\
\ldots \\
\ldots\end{array}$ & $\begin{array}{l}\ldots \\
\ldots \\
\ldots \\
\ldots \\
\cdots \\
\cdots \\
\cdots\end{array}$ & $\begin{array}{l}\ldots \\
\ldots \\
\ldots \\
\ldots \\
\cdots \\
\cdots \\
\ldots\end{array}$ & 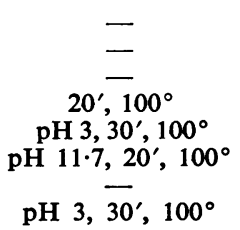 & $\begin{array}{r}10 \\
5 \\
5 \\
5 \\
5 \\
5 \\
5 \\
5\end{array}$ & $\begin{array}{l}109(84 \cdot 6) \\
102(35 \cdot 5) \\
171(79 \cdot 3) \\
313(55 \cdot 1) \\
116(54 \cdot 0) \\
148(101 \cdot 2) \\
385(180 \cdot 4) \\
169(70 \cdot 0)\end{array}$ & $\begin{array}{c}52(29 \cdot 7) \\
77(40 \cdot 4) \\
179(99 \cdot 0) \\
583(148 \cdot 4) \\
73(20 \cdot 8) \\
94(36 \cdot 1) \\
931(140 \cdot 7) \\
144(47 \cdot 9)\end{array}$ \\
\hline
\end{tabular}

Figures in parentheses represent standard deviation 
shown to occur in different animal species and is found also among cotton workers (Merchant $e t$ al., 1975). It thus seems relevant to regard it as an index of pulmonary toxicity.

The results from the experiments demonstrate that the acute leucocyte reaction after exposure to the different cotton dust extracts is related to the number of Gram-negative bacteria present in the preparation. Storage under conditions which could not be expected to influence the composition of any bale cotton constituents caused an increase in the toxicity of the extract when the number of Gramnegative bacteria increased.

For preparations in which discrepancies existed between the leucocyte response and the bacterial count, selective testing of pairs of dusts with equal number of Gram-negatives demonstrated that the rank order found between the size of the Shwartzmann reaction was generally the same as that found for the leucocyte response. The results from this test should be taken only as an indication of a certain trend as the Shwartzmann reaction is not suitable for a precise quantitative evaluation.

The Limulus test is regarded as more specific for endotoxins (Sullivan and Watson, 1974). In order to avoid the influence of other constituents in the different extracts, the test was performed on the different bracts. The significant correlation between the titre in this assay and the number of leucocytes after exposure to the extracts provides strong support for the hypothesis that endotoxins constitute the causative agent. When bract extract or a suspension of Enterobacter aerogenes were subjected to treatment used to decrease the activity of endotoxins, the leucocyte response after exposure diminished or disappeared.

It is difficult to relate the exposure levels used in these experiments with the levels of endotoxin reported by Cavagna, Foa, and Vigliani (1969) which were found to produce byssinosis in cardrooms. An extrapolation of the present data indicates that the levels of endotoxin in the most active preparation tested would cause a leucocyte reaction in humans after exposure to dust levels of about $0.5 \mathrm{mg} / \mathrm{m}^{3}$. This calculation must, however, be verified by further experiments.

The relationship between bronchial symptoms among cotton workers and the bacterial contamination of the cotton dust was discussed by Tuffnell $(1960 \mathrm{a}, \mathrm{b})$. No symptoms were found in humans after an acute exposure to an aerosol of Aspergillus niger or Bacillus pumilus. This confirms previous findings (Rylander et al., 1975a) that the leucocyte reaction is caused by endotoxin producing Gramnegative bacteria, whereas the Bacillus species provoke a very small response if any.

The conclusion that endotoxins are responsible for the acute toxicity of inhaled cotton dusts is in accordance with several earlier observations that histamines are of importance for the reaction. Endotoxins are known to activate complement through the alternative pathway whereby C3a and C5a are released. Histamine can then be released either through the action of these substances (Hook, Sinaganian, and Wahl, 1975) or through that of leucocytes mobilized by the leucotactic activity.

The results of our studies support the hypothesis presented by Pernis et al. (1961) that endotoxins in cotton dusts are important for the development of acute pulmonary reactions among cotton workers. The endotoxin hypothesis was rejected by Antweiler (1961) who reported results from experiments in which the histamine liberating effect was studied using extracts from cotton dusts and endotoxins from $E$. coli and $S$. Abort. equi. No effects were found on plasma histamine levels, arterial blood pressure, respiratory volumes, or destruction of peritoneal mast cells. From an experimental point of view it is difficult to compare these results with those of the present study as different criteria are used. Endotoxins in cotton dust are probably not present in amounts large enough to cause a clinical shock which was one criterion used by Antweiler. With lower doses other effects become more prominent. The effect on the leucocytes is considered to be the most sensitive of the detectable reactions after endotoxin exposure in humans (Wolff, 1973).

As for the other arguments which Antweiler used against the endotoxin hypothesis, our results show that the leucocyte reaction is present after exposure to other parts of the cotton plant including unprocessed cotton fibres. Preliminary data show also that other organic dusts associated with pulmonary disease (hay, sawdust, soya bean dust, and bagasse) may contain endotoxins. The absence of a fever reaction after inhalation of cotton dust can be explained by the development of a pyrogenic tolerance to endotoxin (Wolff, 1973). The amount of endotoxins in the preparations tested in the present experiments seems to be sufficient to provoke the leucocyte reaction at relatively low levels of exposure to the corresponding dust.

The results presented here and in previous publications suggest that the sequence for the acute reaction to cotton dust exposure is as illustrated in Fig. 2. The various acute clinical effects after the activation of complement and histamine liberation should be looked upon only as examples of reactions that may occur independently of one another.

For the further development of the reaction model it is of interest to study the effects which occur after chronic exposure. Preliminary results reported earlier (Rylander and Snella, 1974) demonstrate that the reaction after an acute exposure to a 


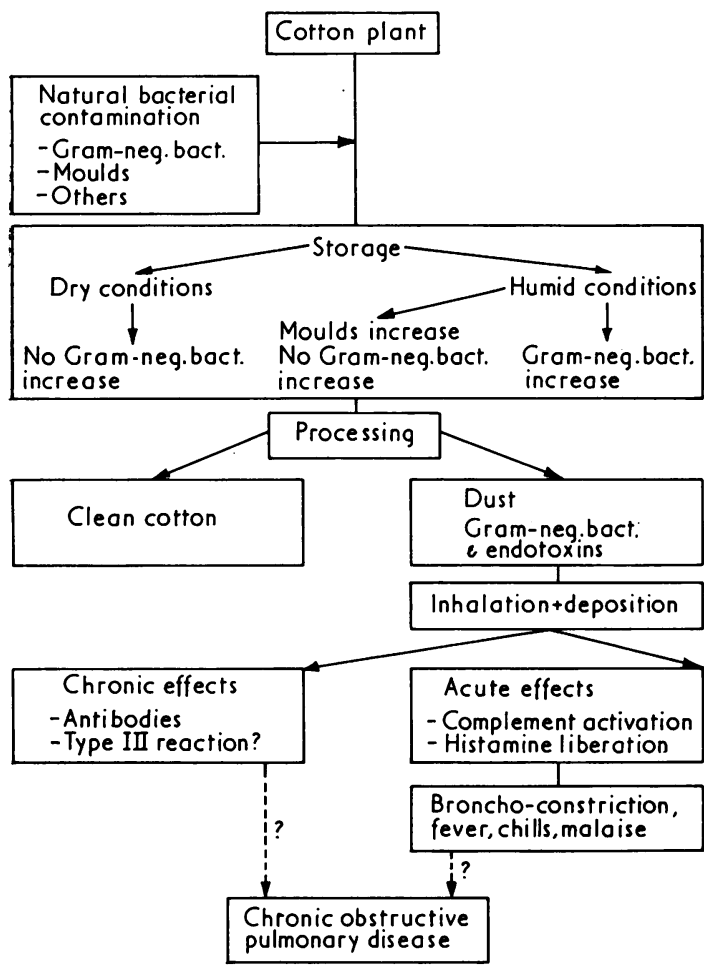

FIG. 2. Suggested model for acute reactions after exposure to cotton dust.

bract dust aerosol is different between animals never exposed and those which have previously been exposed for a 10-day period with a three-day exposure free period before the acute exposure. This result suggests it is possible to develop an animal model for the reaction found in Monday disease. Further experiments will evaluate the relationship between chronic exposure to Gram-negative bacteria and endotoxins and the development of chronic obstructive pulmonary disease.

The results point towards the possibility of establishing quality control for bale cotton in terms of its bacterial contamination or content of endotoxin.

This study was supported by the US Department of Agriculture with funds made available through Cotton Incorporated. The authors are grateful for the helpful advice of Drs Lars-Åke Hansson, Jan Holmgren, and Ejvold Falsen.

\section{References}

Antweiler, H. (1961). Histamine liberation by cotton dust extracts: evidence against its causation by bacterial endotoxins. British Journal of Industrial Medicine, 18, 130-132.

Cavagna, C., Foa, V., and Vigliani, E. C. (1969). Effects in man and rabbits of inhalation of cotton dust or extracts and purified endotoxins. British Journal of Industrial Medicine, 26, 314-321.

Hersh, S. (1973). Personal communication.

Hook, W. A., Sinaganian, R. P., and Wahl, S. M. (1975). Complement-induced histamine release from human basophils. Journal of Immunology, 114, 1185-1190.

Merchant, J. A., Halprin, G. M., Hudson, A. R., Kilburn, K. H., McKenzie, W. N., Hust, D. J., and Bermazohn, P. (1975). Responses to cotton dust. Archives of Environmental Health, 30, 222-229.

Pernis, B., Vigliani, E. C., Cavagna, C., and Finulli, M. (1961). The role of bacterial endotoxin in occupational diseases caused by inhaling vegetable dusts. British Journal of Industrial Medicine, 18, 120-129.

Rylander, R. (1971). Free lung cell studies in cigarette smoke inhalation experiments. Scandinavian Journal of Respiratory Disease, 52, 121-128.

_ and Nordstrand, A. (1974). Pulmonary cell reactions after acute exposure to cotton dust extract. British Journal of Industrial Medicine, 31, 220-223.

,-- , and Snella, M. C. (1975a). Bacterial contamination of organic dusts. Archives of Environmental Health, 30, 137-140.

_ and Snella, M. C. (1974). Bacterial contamination of cotton as a factor determining its pulmonary toxicity. In Proceedings of the ACGIH Symposium on Cotton Dust, Atlanta, 12 and 13 November.

- - _ , and Garcia, I. (1975b). Pulmonary cell response patterns after exposure to airborne bacteria. Scandinavian Journal of Respiratory Disease, 56, 195-200.

Sullivan, J. D. and Watson, S. W. (1974). Factors affecting the sensitivity of Lumulus lysate. Applied Microbiology, 28, 1023-1026.

Tuffnell, P. (1960a). The relationship of byssinosis to the bacteria and fungi in the air of textile mills. British Journal of Industrial Medicine, 17, 304-306.

- (1960b). Experimental byssinosis. British Journal of Industrial Medicine, 17, 307-309.

Wolff, S. M. (1973). Biological effects of bacterial endotoxins in man. In Bacterial Lipopolysaccharides, edited by E. H. Kass and S. M. Wolff, pp. 251-256. University of Chicago Press.

Received for publication 29 September 1975

Accepted for publication 2 February 1976 